\title{
THE PERFORMANCE OF SERVQUAL TO MEASURE SERVICE QUALITY IN PRIVATE UNIVERSITY
}

Leonnard ${ }^{凶}$

\author{
${ }^{\square}$ Faculty of Management, IPMI International Business School, Indonesia, leonnard.ong@ipmi.ac.id
}

\author{
Highlights \\ - The relationship of service quality on satisfaction and loyalty in private university via structural equation modeling (SEM) approach \\ - Only tangible and reliability do significantly affect student satisfaction \\ - $\quad$ Satisfaction significantly affects student loyalty \\ - SERVQUAL is redundant as a model to measure the effect of service quality in educational service
}

\section{Abstract}

The increasing number of educational services has caused a high competition in this industry. In Indonesia, the number of private universities is the highest compared to state universities and other forms of higher education institutions. Ability to predict factors that are important in providing educational services to achieve student satisfaction and make them loyal to the university is highly necessary. In this study, we investigated the main factors of service quality that affect student satisfaction and loyalty by collecting data from 319 students from London School of Public Relation in Jakarta. Structural equation modeling (SEM) was employed to analyze the data through AMOS 24 statistical package. The findings indicated that the main factors influencing student satisfaction in private university are tangible and reliability consisting of: 1) comfortable lecture rooms, 2) adequate library facilities, 3) neat staff appearance, 4) non-discriminatory treatments provided by staff and lecturers, 5) high ability and knowledge provided by staffs and lecturers, and 6) appropriate academic services provided by the university. Student satisfaction with these factors would indirectly lead to loyalty to the university. Finally, service quality measurement through SERVQUAL was redundant as a model to measure the effect of service quality in educational service.

\section{Keywords}

Higher education, loyalty, private university, satisfaction, SERVQUAL

Leonnard (2018) “The Performance of SERVQUAL to Measure Service Quality in Private University”, Journal on Efficiency and Responsibility in Education and Science, Vol. 11, No. 1, pp. 16-21, online ISSN 1803-1617, printed ISSN 2336-2375, doi: 10.7160/ eriesj.2018.110103.

\section{Introduction}

Increasing globalization in the education sector in recent years has led to a growing demand for higher education services (Lim, Yap, \& Lee, 2011). The high demand for education services is also accompanied by the increasing of higher education service providers, particularly private universities (Naidu \& Derani, 2016). Due to the selection system in state universities, private universities become alternative for prospective students who wish to continue their higher education (Rama, 2016). The number of private universities in Indonesia is very high at 3136 units compared to the state universities of only 122 units (Databoks, 2017). The high number of private universities will lead to higher business competition. According to (Chui \& bin Ahmad, 2016), the high competition caused the number of private universities is unable to fulfill the sufficiency of the number of students so that they have to close their study program, while from the number of students, in 2014/2015, 4,156,483 students are enrolled in private universities $(67.93 \%)$ and only as many as 1,962,250 (32.07\%) of students enrolled in state universities (PDDIKTI, 2016), which means that private universities have a very high market potential when managed well compared to state universities.

The provision of high service quality is a fundamental strategy that service providers can afford to maintain and increase their number of students. High service quality will affect the financing, reputation, and popularity of private universities that can guarantee the number of prospective students applying for the next period. In addition, although major consumers of private universities are students, the quality of service they receive indirectly affects industry, parents, communities and governments in their views and decisions on private universities (Kitchroen, 2004). Research on service quality in educational service has been widely applied (Zammuto, Keaveney, \& O’Connor, 1996; Abdullah, 2006a, 2006b, 2006c; Manaf, Ahmad, \& Ahmed, 2013; Đonlagić \& Fazlić, 2015; Chui \& bin Ahmad, 2016; Naidu \& Derani, 2016). Most of the studies employ the SERVQUAL and SERVPERF models. However, the application in Indonesia, especially in private universities is still limited. Previously, Susanti, Sule, \& Sutisna (2015) and Hasbullah \& Yusoff (2017) have conducted research on service quality in educational services in Indonesia. But their research does not specifically focus on private universities. Therefore, in this study, we investigated service quality in the private university in Indonesia. This study contributed by adding a new perspective on service quality predictors on higher educational services and identified which dimensions of service quality were the most influential on student satisfaction. Since, the number of private universities in Indonesia is overwhelming and there is a possibility of increasing the number in the future, then the results of this study are beneficial as a consideration for existing university managers, as well as input for upcoming private universities.

\section{Literature}

\section{Service quality in educational services}

Services on educational services have the same characteristics as services in other service sectors, as the existence of intangibility, inseparability, heterogeneity, perishability, and lack of ownership (Zeithaml, Parasuraman, \& Berry, 1985; Parasuraman, Zeithaml, \& Berry, 1988; Gruber et al., 2010). Because of these similarities, according to Hemsley-Brown \& Oplatka (2006), educational institutions need to apply marketoriented and profit-oriented principles to achieve competitive 
advantage and institutional sustainability. One of the basic principles applied to achieve both is to provide high service quality. The ability of service quality to meet the expectations of students will determine the level of student satisfaction, university costs and benefits, student switching behavior, and positive behavior such as word of mouth and repurchase intention (Crosby, 1979; Bolton \& Drew, 1991; Cronin Jr \& Taylor, 1992; Rust \& Zahorik, 1993; Stodnick \& Rogers, 2008; Leonnard et al., 2015). In the measurement of service quality in educational services, perceived service quality is used to compare service expectation with perception of real service performance, as well as service quality measurement in other service sectors (Zeithaml, Parasuraman, \& Berry, 1990). When real performance exceeds the expectations of the students, there is positive disconfirmation that will result in satisfaction (Buttle, 1996). This satisfaction will determine the long-term competitive advantage and sustainability of the university.

\section{SERVQUAL approach to measure service quality in educational services}

According to Clewes (2003) and Marzo-Navarro, PedrajaIglesias, \& Pilar Rivera-Torres, 2005), there is no agreement on the best model in measuring educational service quality. Each model used has its own advantages and disadvantages. In general, the most commonly used models for measuring service quality in educational services are SERVQUAL (Parasuraman et al., 1988), SERVPERF (Abdullah, 2006b), and HEdPERF (Abdullah, 2006a). Of the three models, SERVQUAL is the most widely used model. According to Parasuraman et al. (1988), the core of this model is the ability to measure whether the real performance of services exceeds consumer expectations. To measure this, five dimensional measurements consisting of tangibles, reliability, responsiveness, assurance, and empathy are used. Tangibles are related to the physical condition and availability of facilities and human resources. Reliability relates to the ability of service providers to provide services in accordance with what is promised. Responsiveness relate to the ability of service providers to provide the best service to consumers. Assurance deals with the knowledge and skills of service provider employees. Last, empathy deals with the personal attention provided by the service provider to the consumers. The use of SERVQUAL in educational services has been widely demonstrated in previous studies (Zammuto, Keaveney, \& O’Connor, 1996; Browne et al., 1998; Oldfield \& Baron, 2000; de Jager \& Gbadamosi, 2013; Chui \& bin Ahmad, 2016; Naidu \& Derani, 2016). Based on the above analysis, the research hypotheses to be tested are as follows:

\section{Research hypothesis 1 (H1):}

Perception of tangible dimension has a positive relationship on overall service quality perceptions toward educational services Research hypothesis 2 (H2):

Perception of reliability dimension has a positive relationship on overall service quality perceptions toward educational services

\section{Research hypothesis 3 (H3):}

Perception of responsiveness dimension has a positive relationship on overall service quality perceptions toward educational services

\section{Research hypothesis 4 (H4):}

Perception of assurance dimension has a positive relationship on overall service quality perceptions toward educational services Research hypothesis 5 (H5):

Perception of empathy has a positive relationship on overall service quality perceptions toward educational services

\section{The relationship between service quality and satisfaction}

Previous studies have proven that high service quality in educational services has a significant effect on student satisfaction (Cronin Jr \& Taylor, 1992; de Jager \& Gbadamosi, 2013; Leonnard et al., 2013; Mustaffa et al., 2016; Kasiri, Cheng, Sambasivan, \& Sidin, 2017, Leonnard, 2017). Students' satisfaction is achieved when real performance of educational services exceeds student expectations (Parasuraman et al., 1988). Student expectations are student expectations of the quality of services provided by educational services while performance is the real performance of the service quality provided by educational services (Kottler \& Keller, 2003). According to (DeShields Jr, Kara, \& Kaynak, 2005), the main predictors of student satisfaction with educational services are performance of faculty, staff and classes. Furthermore, according to (de Jager \& Gbadamosi, 2013), predictors of student satisfaction with educational services are internationalization, marketing and support, access, staff and academic quality, accommodation, and facilities. Based on the above analysis, the research hypothesis to be tested is as follows:

Research hypothesis (H6):

Service quality has a positive relationship on student satisfaction.

\section{Data and Methods \\ Reliability}

SERVQUAL approach was adopted to measure educational service quality which consisted of tangibles, reliability, responsiveness, assurance, and empathy (Parasuraman et al., 1988). The student satisfaction was measured by the expectations and performance dimensions of the educational service (Kotler $\&$ Keller, 2003). Indicators of each dimension can be seen in Appendix A1. Furthermore, to measure the construct variables, a five-point likert scale was employed $(1=$ strongly disagree and 5 = strongly agree). Data were collected from 319 students of London School of Public Relations in Jakarta. Data collection was carried out by employing stratified random sampling method. Finally, data analysis was carried out by employing Structural Equation Modeling (SEM) and software of AMOS 24 statistical package

\section{Research Instrument}

To test the reliability of the dimensions used to measure each construct, cronbach's alpha test was employed. The test results by using SPSS 20, indicated that all item values were $>0.600$ and were reliable to measure each construct (Hair et al., 1998) (Table 1). 


\begin{tabular}{|c|c|c|c|}
\hline Constructs & & Dimensions & \begin{tabular}{|c|} 
Cronbach's \\
Alpha
\end{tabular} \\
\hline \multirow{3}{*}{ Tangibles } & Q1 & Neat staff appearance & \multirow{3}{*}{0.765} \\
\hline & Q2 & Adequate library facilities & \\
\hline & Q3 & Comfortable lecture rooms & \\
\hline \multirow{3}{*}{ Reliability } & Q4 & $\begin{array}{l}\text { High ability and knowledge provided } \\
\text { by staffs and lecturers }\end{array}$ & \multirow{3}{*}{0.822} \\
\hline & Q5 & $\begin{array}{l}\text { Non-discriminatory treatments } \\
\text { provided by staff and lecturers }\end{array}$ & \\
\hline & Q6 & $\begin{array}{l}\text { Appropriate academic services } \\
\text { provided by the university }\end{array}$ & \\
\hline \multirow{3}{*}{ Responsiveness } & Q7 & Fast response & \multirow{3}{*}{0.811} \\
\hline & Q8 & Accurate academic services & \\
\hline & Q9 & Quickly complain handlings & \\
\hline \multirow{3}{*}{ Assurance } & Q10 & High quality service standards & \multirow{3}{*}{0.750} \\
\hline & Q11 & High-quality administrative services & \\
\hline & Q12 & High-quality academic services & \\
\hline \multirow[b]{2}{*}{ Empathy } & Q13 & Serving students friendly & \multirow[b]{2}{*}{0.728} \\
\hline & Q14 & $\begin{array}{l}\text { Provides information that is easy to } \\
\text { understand }\end{array}$ & \\
\hline \multirow{3}{*}{ Satisfaction } & S1 & Study facilities as expected & 0.824 \\
\hline & S2 & $\begin{array}{l}\text { Quality of staff and lecturers as } \\
\text { expected }\end{array}$ & \\
\hline & S3 & $\begin{array}{l}\text { Environmental conditions and learning } \\
\text { atmosphere as expected }\end{array}$ & \\
\hline \multirow{3}{*}{ Loyalty } & L1 & $\begin{array}{l}\text { I told the superiority of this university } \\
\text { to others }\end{array}$ & 0.857 \\
\hline & $\mathrm{L} 2$ & \begin{tabular}{|l|}
$\begin{array}{l}\text { I recommend this university to the } \\
\text { public }\end{array}$ \\
\end{tabular} & \\
\hline & L3 & $\begin{array}{l}\text { I will remain loyal to this university } \\
\text { until my studies are completed as well } \\
\text { as for my study in the future }\end{array}$ & \\
\hline
\end{tabular}

Table 1: Reliability test results (source: own calculation from AMOS 24 software)

\section{SEM Model and Solution Procedure}

The first order confirmatory factor analysis (CFA) was performed first in the overall dataset through the maximum likelihood (ML) estimate. The first order CFA was employed to test the validity of a theoretical construct (Byrne \& Gavin, 1996). The constraints employed were tangible, reliability, responsiveness, assurance, and empathy (related to 14 dimensions). Afterwards, the CFA results were evaluated whether the undimensionality and reliability of each contract were confirmed. The fit indicators evaluated were RMSEA, CMIN / DF, RMR, GFI, NFI, IFI, and CFI. In addition, the evaluation of the feasibility of parameter estimation, standard error compatibility, significance of parameter estimation, and construct validity were also conducted. The structural relationships between variables are displayed in Figure 1. Hereafter, the structural equation modeling model (SEM) was performed by employing AMOS 24 software to notice the relationship between service quality dimensions (tangible, reliability, responsiveness, assurance, and empathy) with satisfaction and loyalty (related to 20 dimensions). SEM is an appropriate analytical technique for testing the relationship between theoretical constructs and visualized through path diagrams (Hox \& Bechger, 2007). The model validation, then evaluated through convergent, discriminant validity, and reliability.

\section{Results and Discussions}

The result of the fit analysis indicated that the RMSEA value was 0.08 (according to recommended rate level), CMIN/DF of 3.216 (valid), RMR of 0.049 (valid), GFI is 0.860 (moderate), NFI is 0.866 (moderate), IFI is 0.904 (valid), CFI is 0.903 (valid). Although there were some indicators that did not meet the criteria goodness of fit, overall the model has met the criteria of goodness of fit (Meesala \& Paul, 2016). The relationship between each latent variable was displayed in Figure 1.

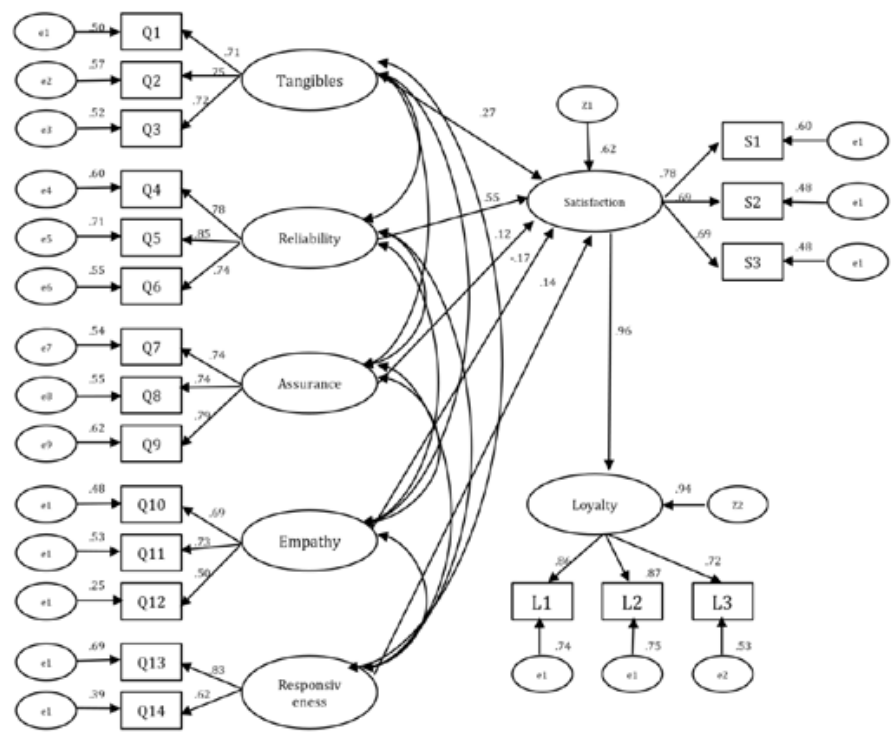

Figure 1: Path diagram (source: own calculation from AMOS 24 software)

Service quality dimensions that positively affected student satisfaction were only tangible $(0.283)$ and reliability $(0.580)$ (alpha 5\%). While the other three dimensions, namely responsiveness, assurance, and empathy were not proven to have significant effects (Table 2).

\begin{tabular}{|c|c|c|c|c|}
\hline & Estimate & \begin{tabular}{|c|} 
Standardized \\
loadings
\end{tabular} & S.E. & C.R \\
\hline Tangibles $\rightarrow$ Satisfaction & 0.283 & $0.269^{* *}$ & 0.129 & 2.197 \\
\hline Reliability $\rightarrow$ Satisfaction & 0.580 & $0.552 * * *$ & 0.144 & 4.032 \\
\hline Responsiveness $\rightarrow$ Satisfaction & 0.116 & 0.118 & 0.293 & 0.395 \\
\hline Assurance $\rightarrow$ Satisfaction & -0.278 & -0.174 & 0.534 & -0.521 \\
\hline Empathy $\rightarrow$ Satisfaction & 0.173 & 0.141 & 0.129 & 1.346 \\
\hline Satisfaction $\rightarrow$ Loyalty & 0.884 & 0.956 & 0.078 & 11.277 \\
\hline
\end{tabular}

Table 2: Result of regression weights (source: own calculation from AMOS 24 software)

The significant effect of tangible dimensions on student satisfaction supported previous studies (Hill \& Epps, 2010; Manaf, Ahmad, \& Ahmed, 2013; Hoque et al., 2013; El-Hilali, Al-Jaber, \& Hussein, 2015). In educational services, facilities and physical environments had direct effects on student satisfaction. Similarly, the direct effect of service reliability supported the previous study by (Pathmini, 2016). The ability of private university to provide services in accordance with what the private university promised will increase student satisfaction. However, from the perspective of the direct effect of service quality on student satisfaction, the use of SERVQUAL to measure the quality of service in the field of educational services is considered redundant. This becomes very interesting considering most of the previous studies on educational services uses SERVQUAL approach to analyze the effect of service quality on student satisfaction (Zammuto, Keaveney, \& O'Connor, 1996; Browne et al., 1998; de Jager \& Gbadamosi, 2013; Chui \& bin Ahmad, 2016; Naidu \& Derani, 2016). From table 1, it was indicated that of the five dimensions, only two dimensions significantly affect student satisfaction. Reliability had a greater direct effect on satisfaction (0.552) than tangibles (0.269). Both dimensions had an indirect effect of 0.250 (tangibles) and 0.513 (reliability) of loyalty through 
a mediating variable of students' satisfaction. In addition, the total effects of tangibles and reliability on loyalty were 0.250 and 0.513 respectively (Table 3 ).

\begin{tabular}{|l|l|c|c|c|c|c|}
\hline & Empathy & Assurance & Responsiveness & Reliability & Tangible & Satisfaction \\
\hline Direct effects \\
\hline Satisfaction & 0.173 & -0.278 & 0.116 & 0.580 & 0.283 & 0.000 \\
\hline Loyalty & 0.000 & 0.000 & 0.000 & 0.000 & 0.000 & 0.884 \\
\hline Indirect effects \\
\hline Satisfaction & 0.000 & 0.000 & 0.000 & 0.000 & 0.000 & 0.000 \\
\hline Loyalty & 0.153 & -0.246 & 0.102 & 0.513 & 0.250 & 0.000 \\
\hline Total effects \\
\hline Satisfaction & 0.173 & -0.278 & 0.116 & 0.580 & 0.283 & 0.000 \\
\hline Loyalty & 0.153 & -0.248 & 0.102 & 0.513 & 0.250 & 0.884 \\
\hline
\end{tabular}

Table 3: Direct, Indirect, and Total effects (source: own calculation from AMOS 24 software)

From table 4, the main dimension of tangibles was comfortable lecture room (0.776), while the main dimension of reliability was the non-discriminatory treatments provided by staff and lecturers (0.864). Furthermore, the main dimension of responsiveness was quickly complaint handlings $(0.801)$, and the main dimension of assurance was a high administrative service (0.787). Finally, the main dimension of empathy was serving students friendly (0.812). All significant dimensions affect each variable with alpha $1 \%$ (Table 3 ). All values of standardized loadings were above $0.50, \mathrm{GFI}=0.927, \mathrm{AGFI}=0.886, \mathrm{RMR}=0.065, \mathrm{CMIN} /$ $\mathrm{DF}=2.427, \mathrm{RMSEA}=0.06$, PCLOSE $=0.017$ indicated the general model had met the goodness of fit.

\begin{tabular}{|c|c|c|c|c|}
\hline & Estimate & $\begin{array}{c}\text { Standardized } \\
\text { loadings }\end{array}$ & S.E. & C.R \\
\hline Q1 $\rightarrow$ Tangibles & 0.960 & $0.733 * * *$ & 0.084 & 11.500 \\
\hline Q2 $\rightarrow$ Tangibles & 0.922 & $0.747 * * *$ & 0.093 & 10.752 \\
\hline Q3 $\rightarrow$ Tangibles & 1.000 & $0.776 * * *$ & & \\
\hline Q4 $\rightarrow$ Reliability & 1.122 & $0.793 * * *$ & 0.081 & 13.220 \\
\hline Q5 $\rightarrow$ Reliability & 1.210 & $0.864 * * *$ & 0.081 & 14.333 \\
\hline Q6 $\rightarrow$ Reliability & 1.000 & $0.742 * * *$ & & \\
\hline Q7 $\rightarrow$ Responsiveness & 0.957 & $0.749 * * *$ & 0.069 & 13.614 \\
\hline Q8 $\rightarrow$ Responsiveness & 0.974 & $0.753 * * *$ & 0.068 & 13.927 \\
\hline Q9 $\rightarrow$ Responsiveness & 1.000 & $0.801 * * *$ & & \\
\hline Q10 $\rightarrow$ Assurance & 1.241 & $0.764 * * *$ & 0.182 & 7.748 \\
\hline Q11 $\rightarrow$ Assurance & 1.414 & $0.787 * * *$ & 0.187 & 8.094 \\
\hline Q12 $\rightarrow$ Assurance & 1.000 & $0.626^{* * *}$ & & \\
\hline Q13 $\rightarrow$ Empathy & 1.224 & $0.812 * * *$ & 0.168 & 7.705 \\
\hline Q14 $\rightarrow$ Empathy & 1.000 & $0.627 * * *$ & & \\
\hline
\end{tabular}

Table 4: Results of service quality regression weights (source: own calculation from AMOS 24 software)

The relationship between each latent variable of service quality was displayed in Figure 2.

Based on the empirical results, it is inferred that only two dimensions of SERVQUAL had an affect on student satisfaction (research hypothesis 3, 4, and 5 are rejected). This result is in accordance with Meesala \& Paul (2016) which measures service quality in the hospital by using SERVQUAL (research hypothesis 6 is accepted). For managers of higher education institutions, the results of this study are useful in providing guidance on the main dimensions of service quality in educational services so that education managers can focus on those dimensions. In relation to the level of satisfaction, the physical state of the university facilities, the qualifications of staff and lecturers, quality and non-discriminatory services become the main constructs. The comfortable lecture room is the main dimension of physical facilities that the university needs to provide. This is because the lecture room is the main place for students to receive lectures.
Less comfortable rooms, will indirectly affect the quality of absorbing lectures well. Furthermore, non-discriminatory treatment by staff and lecturers becomes the main dimension of the reliability of services provided by the private university. The services provided by the university should be provided without distinction of race, ethnicity, culture, national origin, social status or educational level. While for the researcher in the field of service management, the result of this research is useful in evaluating the reliability and performance of the use of SERVQUAL in the field of education services to predict student satisfaction. The use of other methods such as SERVPERF or HEdPERF is suggested to be able to more specifically analyze the factors of service quality predictors in higher education (Abdullah, 2006b).

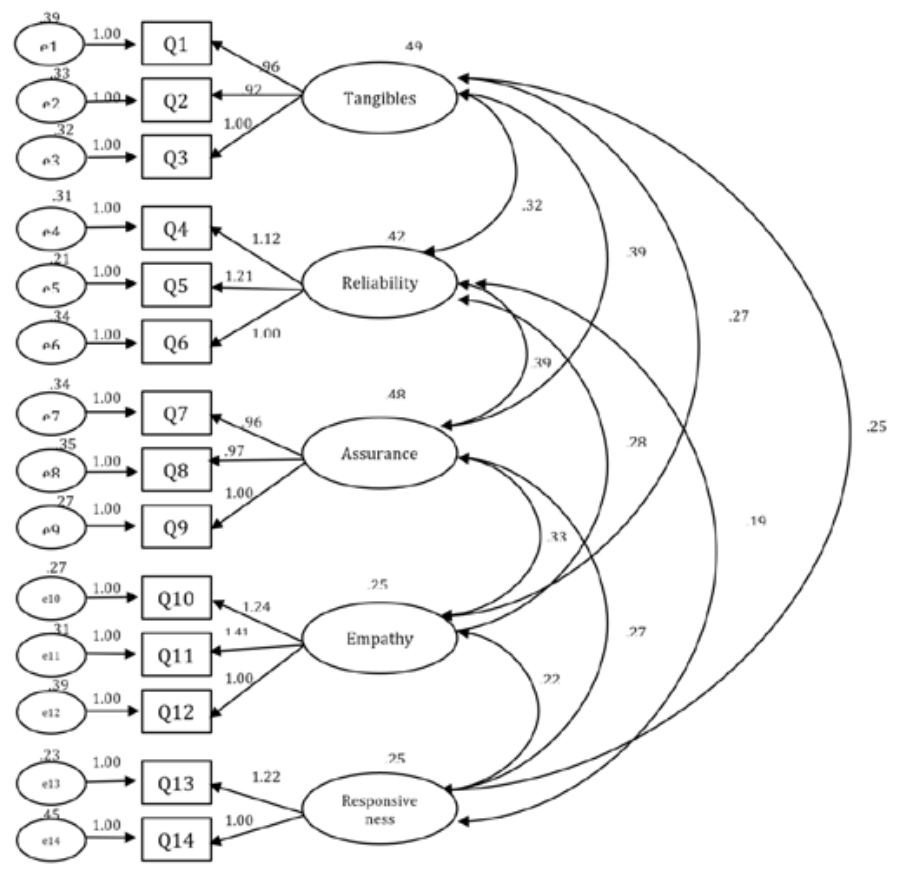

Figure 2: Path diagram of service quality (source: own calculation from AMOS 24 software)

\section{Conclusion and Direction for Further Research}

Some conclusions drawn from this research are:

- Factors affecting student satisfaction in the private university are tangible and reliability consisting of: 1) comfortable lecture rooms, 2) adequate library facilities, 3) neat staff appearance, 4) non-discriminatory treatments provided by staff and lecturers, 5) high ability and knowledge provided by staffs and lecturers, and 6) appropriate academic services provided by the university. Satisfaction significantly affects student loyalty.

- SERVQUAL is redundant as a model to measure the effect of service quality in educational service.

- However, this study has some limitations. First, the institutions that are the object of this research are private universities, so in the next research the SERVQUAL model needs to be applied to other educational institutions such as state universities, or at different levels of education such as senior or junior high school to get a more comprehensive conclusion on the relevance of the use this model is in the educational sector. In addition, the use of more relevant models is strongly recommended to measure the effect of service quality on satisfaction with educational services. 


\section{References}

Abdullah, F. (2006a) 'The development of HEdPERF: a new measuring instrument of service quality for the higher education sector', International Journal of Consumer Studies, Vol. 30, No. 6, pp. 569-581. http://dx.doi.org/10.1111/j.14706431.2005.00480.x

Abdullah, F. (2006b) 'Measuring service quality in higher education: HEdPERF versus SERVPERF', Marketing Intelligence \& Planning, Vol. 24, No. 1, pp. 31-47. https://doi. org/10.1108/02634500610641543

Abdullah, F. (2006c) 'Measuring service quality in higher education: three instruments compared', International Journal of Research \& Method in Education, Vol. 29, No. 1, pp. 71-89. https://doi.org/10.1080/01406720500537445

Bolton, R.N. \& Drew, J.H. (1991) 'A longitudinal analysis of the impact of service changes on customer attitudes', The Journal of Marketing, Vol. 55, No. 1, pp. 1-9. https://doi. org/10.2307/1252199

Browne, B.A., Kaldenberg, D.O., Browne, W.G. \& Brown, D.J. (1998) 'Student as customer: Factors affecting satisfaction and assessments of institutional quality', Journal of Marketing for Higher Education, Vol. 8, No. 3, pp. 1-14. https://doi. org/10.1300/J050v08n03 01

Buttle, F. (1996) 'SERVQUAL: Review, critique, research agenda', European Journal of marketing, Vol. 30, No. 1, pp. 8-32. https://doi.org/10.1108/03090569610105762

Byrne, B. M., \& Gavin, D. A. (1996) The Shavelson Model revisited: Testing for the structure of academic self-concept across pre-, early, and late adolescents. Journal of Educational Psychology, 88(2), 215. https://doi.org/10.1037/00220663.88.2.215

Chui, T.B. \& bin Ahmad, M.S. (2016) 'Evaluation of service quality of Private Higher education using service improvement matrix. Procedia-Social and Behavioral Sciences, 224, pp. 132140. https://doi.org/10.1016/j.sbspro.2016.05.417

Clewes, D. (2003) 'A student-centred conceptual model of service quality in higher education', Quality in Higher Education, Vol. 9, No. 1, pp. 69-85. https://doi.org/10.1080/13538320308163

Cronin Jr, J.J. \& Taylor, S.A. (1992) 'Measuring service quality: a reexamination and extension', The journal of marketing, pp. 55-68. https://doi.org/10.2307/1252296

Crosby, P.B. (1980) Quality is free: The art of making quality certain. New York: New American Library.

Databoks. (2017) Berapa jumlah perguruan tinggi di Indonesia? [Online], Available: https://databoks.katadata.co.id/ datapublish/2017/05/05/berapa-jumlah-perguruan-tinggi-diindonesia [30 October 2017].

de Jager, J. \& Gbadamosi, G. (2013) 'Predicting students' satisfaction through service quality in higher education', The International Journal of Management Education, Vol. 11, No. 3, pp. 107-118. https://doi.org/10.1016/j.ijme.2013.09.001

DeShields Jr, O.W., Kara, A. \& Kaynak, E. (2005) 'Determinants of business student satisfaction and retention in higher education: Applying Herzberg's two-factor theory', International journal of educational management, Vol. 19, No. 2, pp. 128-139. https:// doi.org/10.1108/09513540510582426

Đonlagić, S. and Fazlić, S. (2015) 'Quality assessment in higher education using the SERVQUALQ model', Management: journal of contemporary management issues, Vol. 20, No. 1, pp. 39-57. Retrieved from https://hrcak.srce.hr/141588.

El-Hilali, N., Al-Jaber, S. \& Hussein, L. (2015) 'Students' satisfaction and achievement and absorption capacity in higher education', Procedia-Social and Behavioral Sciences, Vol. 177, pp. 420-427. https://doi.org/10.1016/j.sbspro.2015.02.384
Gruber, T., Fuß, S., Voss, R. \& Gläser-Zikuda, M. (2010) 'Examining student satisfaction with higher education services: Using a new measurement tool'. International Journal of Public Sector Management, Vol. 23, No. 2, pp. 105-123. https://doi. org/10.1108/09513551011022474

Hair, J. F., Black, W. C., Babin, B. J., Anderson, R. E. \& Tatham, R. L. (1998) 'Multivariate data analysis', Upper Saddle River, New Jersey: Prentice hall.

Hasbullah, A. \& Yusoff, W.Z.W. (2017) 'A Framework Study of Service Quality on Higher Education Institution (HEI)', The Social Sciences, Vol. 12, No. 6, pp. 925-931. Retrieved from http://docsdrive.com/pdfs/medwelljournals/ sscience/2017/925-931.pdf.

Manaf, N. H. A., Ahmad, K. \& Ahmed, S. (2013) 'Critical factors of service quality in a graduate school of Malaysia'. International Journal of Quality and Service Sciences, Vol. 5, No. 4, pp. 415431. https://doi.org/10.1108/IJQSS-07-2012-0006

Hemsley-Brown, J. \& Oplatka, I. (2006) 'Universities in a competitive global marketplace: A systematic review of the literature on higher education marketing'. International Journal of public sector management, Vol. 19, No. 4, pp. 316-338. https://doi.org/10.1108/09513550610669176

Hill, M.C. \& Epps, K.K. (2010) 'The impact of physical classroom environment on student satisfaction and student evaluation of teaching in the university environment', Academy of Educational Leadership Journal, Vol. 14, No. 4, pp. 65. Retrieved from https://pdfs.semanticscholar.org/b1c7/9d8585d 8cc3d7236dd798350f01af5e4399f.pdf.

Hoque, K.E., Razak, A.Z.A., Othman, A.J., Mishra, P.K. \& Samad, R.S.A. (2013) 'Quality services as perceived by students of International and Public schools', Life Science Journal, Vol. 10, No. 2, pp. 74-78. Retrieved from http://eprints.um.edu. my/9789/1/00005891_92949.pdf.

Hox, J. J., \& Bechger, T. M. (2007). An introduction to structural equation modeling. Family Science Review, Vol. 11, pp. 354373. Retrieved from http://joophox.net/publist/semfamre.pdf.

Kasiri, L.A., Cheng, K.T.G., Sambasivan, M. and Sidin, S.M. (2017) 'Integration of standardization and customization: Impact on service quality, customer satisfaction, and loyalty'. Journal of Retailing and Consumer Services, Vol. 35, pp. 91-97. https://doi.org/10.1016/j.jretconser.2016.11.007

Kitchroen, K. (2004) 'Literature review: Service quality in educational institutions', ABAC journal, Vol 24, No. 2.

Kottler, P. \& Keller, K.L. (2003) Marketing management. Analyse, Planung, Umsetzung und.

Leonnard, L., Daryanto, H. K., Sukandar, D., \& Yusuf, E. Z. (2013). The loyalty model of private university student, study case: stikom london school of public relation. International Journal of Information Technology and Business Management, Vol. 20, No. 1.

Leonnard, L., Daryanto, H.K., Sukandar, D. \& Yusuf, E.Z. (2015) 'The Loyalty Model of Private University Student', International Research Journal of Business Studies, Vol. 7, No. 1, pp. 55-68. https://doi.org/10.21632/irjbs.7.1.55-68

Leonnard, L. (2017). Measuring grocery stores service quality in indonesia: a retail service quality scale approach. Studies and Scientific Researches. Economics Edition, No. 26. http://dx.doi. org/10.29358/sceco.v0i26.397

Lim, Y.M., Yap, C.S. \& Lee, T.H. (2011) 'Destination choice, service quality, satisfaction, and consumerism: International students in Malaysian institutions of higher education'. African journal of business management, Vol. 5, No. 5, pp. 1691. https:// doi.org/10.5897/AJBM10.610 
Marzo-Navarro, M., Pedraja-Iglesias, M. \& Pilar RiveraTorres, M. (2005) 'Measuring customer satisfaction in summer courses', Quality Assurance in Education, Vol. 13, No. 1, pp. 53-65. https://doi.org/10.1108/09684880510578650

Meesala, A. \& Paul, J. (2016) 'Service quality, consumer satisfaction and loyalty in hospitals: Thinking for the future', Journal of Retailing and Consumer Services Vol. 40, pp. 261269. https://doi.org/10.1016/j.jretconser.2016.10.011

Mustaffa, W.S.W., Ali, M.H., Bing, K.W. \& Rahman, R.A. (2016) 'Investigating the relationship among service quality, emotional satisfaction and favorable behavioral intentions in higher education service experience', Procedia-Social and Behavioral Sciences, Vol. 224, pp. 499-507. https://doi. org/10.1016/j.sbspro.2016.05.426

Naidu, P. \& Derani, N.E.S. (2016) 'A comparative study on quality of education received by students of private universities versus public universities. Procedia Economics and Finance, Vol. 35, pp. 659-666. https://doi.org/10.1016/S22125671(16)00081-2

Oldfield, B.M. \& Baron, S. (2000) 'Student perceptions of service quality in a UK university business and management faculty', Quality Assurance in education, Vol. 8, No. 2, pp. 8595. https://doi.org/10.1108/09684880010325600

Parasuraman, A., Zeithaml, V.A. \& Berry, L.L. (1988) 'Servqual: A multiple-item scale for measuring consumer perception of service quality', Journal of retailing, Vol. 64, No. 1, pp. 12. Retrived from https://www.researchgate.net/profile/ Valarie_Zeithaml/publication/225083802_SERVQUAL_A_ multiple-_Item_Scale_for_measuring_consumer_perceptions of_service_quality/links/5429a4540cf27e 39 fa 8 e $6531 /$ SERVQUAL-A-multiple-Item-Scale-for-measuring-consumerperceptions-of-service-quality.pdf

Pathmini, M.G.S. (2016) 'Impact of service reliability on student satisfaction in newly established public sector universities in Sri Lanka: Perspective on undergraduates in management faculties', InternationalJournalonGlobalBusinessManagement\&Research, Vol. 5, No. 1, pp. 11. Retrieved from https://www.researchgate. net/profile/Pathmini_S/publication/295257431_Impact_of_ Service_Quality_on_Students\%27_Satisfaction_in_Newly_Established_Public_Sector_Universities_in_Sri_Lanka_ Study_Based_on_The_Faculty_of_Management_Studies/ links/56c8b94308aee3cee53d74cc/Impact-of-Service-Qualityon-Students-Satisfaction-in-Newly-Established-Public-SectorUniversities-in-Sri-Lanka-Study-Based-on-The-Faculty-ofManagement-Studies.pdf

Pangkalan Data Pendidikan Tinggi (PDDIKTI), (2016) Statistik Pendidikan Tinggi 2014/2015. Jakarta: Kementerian Riset, Teknologi, dan Pendidikan Tinggi Republik Indonesia.

Rama, C. (2016) 'The new state of private universities in Latin America', A Global Perspective on Private Higher Education, p. 229. https://doi.org/10.1016/B978-0-08-100872-0.00014-8

Rust, R.T. \& Zahorik, A.J. (1993) 'Customer satisfaction, customer retention, and market share', Journal of retailing, Vol. 69, No. 2, pp. 193-215. https://doi.org/10.1016/00224359(93)90003-2

Stodnick, M. \& Rogers, P. (2008) 'Using SERVQUAL to measure the quality of the classroom experience', Decision Sciences Journal of Innovative Education, Vol. 6, No. 1, pp. 115-133. https://doi.org/10.1111/j.1540-4609.2007.00162.x

Susanti, E., Sule, E.T. \& Sutisna, H. (2015) 'The impact of internal and external service quality (A case study among lecturers and students)', Mediterranean Journal of Social Sciences, Vol. 6, No. 5, p. 77. https://doi.org/10.5901/mjss.2015.v6n5s5p77

Zammuto, R.F., Keaveney, S.M. \& O’Connor, E.J. (1996)
'Rethinking student services: assessing and improving service quality', Journal of Marketing for Higher Education, Vol. 7, No. 1, pp. 45-70. https://doi.org/10.1300/J050v07n01_05

Zeithaml, V.A., Parasuraman, A. \& Berry, L.L. (1985) 'Problems and strategies in services marketing', The Journal of Marketing, pp. 33-46. https://doi.org/10.2307/1251563

Zeithaml, V.A., Parasuraman, A. \& Berry, L.L. (1990) Delivering quality service: Balancing customer perceptions and expectations, New York: Simon and Schuster.

\section{Appendix A \\ Description of construct dimensions}

\begin{tabular}{|c|c|c|}
\hline Constructs & & Dimensions \\
\hline \multirow{3}{*}{ Tangibles } & Q1 & Neat staff appearance \\
\hline & Q2 & Adequate library facilities \\
\hline & Q3 & Comfortable lecture rooms \\
\hline \multirow{3}{*}{ Reliability } & Q4 & $\begin{array}{l}\text { High ability and knowledge provided by staffs and } \\
\text { lecturers }\end{array}$ \\
\hline & Q5 & $\begin{array}{l}\text { Non-discriminatory treatments provided by staff } \\
\text { and lecturers }\end{array}$ \\
\hline & Q6 & $\begin{array}{l}\text { Appropriate academic services provided by the uni- } \\
\text { versity }\end{array}$ \\
\hline \multirow{3}{*}{ Responsiveness } & Q7 & Fast response \\
\hline & Q8 & Accurate academic services \\
\hline & Q9 & Quickly complain handlings \\
\hline \multirow{3}{*}{ Assurance } & Q10 & High quality service standards \\
\hline & Q11 & High-quality administrative services \\
\hline & Q12 & High-quality academic services \\
\hline \multirow{2}{*}{ Empathy } & Q13 & Serving students friendly \\
\hline & Q14 & Provides information that is easy to understand \\
\hline \multirow{3}{*}{ Satisfaction } & $\mathrm{S} 1$ & Study facilities as expected \\
\hline & $\mathrm{S} 2$ & Quality of staff and lecturers as expected \\
\hline & $\mathrm{S} 3$ & $\begin{array}{l}\text { Environmental conditions and learning atmosphere } \\
\text { as expected }\end{array}$ \\
\hline \multirow{3}{*}{ Loyalty } & L1 & I told the superiority of this university to others \\
\hline & L2 & I recommend this university to the public \\
\hline & L3 & $\begin{array}{l}\text { I will remain loyal to this university until my studies } \\
\text { are completed as well as for my study in the future }\end{array}$ \\
\hline
\end{tabular}

Table A1: The dimensions of constructs (source: own calculation) 